\title{
Climatological Behavior of Precipitating Clouds in the Northeast Region of Brazil
}

\author{
Rayana Santos Araújo Palharini and Daniel Alejandro Vila \\ Center for Weather Forecasting and Climate Research, Cachoeira Paulista, SP, Brazil \\ Correspondence should be addressed to Rayana Santos Araújo Palharini; rayana.palharini@gmail.com
}

Received 28 February 2017; Accepted 24 April 2017; Published 29 May 2017

Academic Editor: Tomeu Rigo

Copyright ( 2017 Rayana Santos Araújo Palharini and Daniel Alejandro Vila. This is an open access article distributed under the Creative Commons Attribution License, which permits unrestricted use, distribution, and reproduction in any medium, provided the original work is properly cited.

\begin{abstract}
This study aims to analyze the climatological classification of precipitating clouds in the Northeast of Brazil using the radar on board the Tropical Rainfall Measuring Mission (TRMM) satellite. Thus, for this research a time series of 15 years of satellite data (period 1998-2012) was analyzed in order to identify what types of clouds produce precipitation estimated by Precipitation Radar (PR) and how often these clouds occur. From the results of this work it was possible to estimate the average relative frequency of each type of cloud present in weather systems that influence the Northeast of Brazil. In general, the stratiform clouds and shallow convective clouds are the most frequent in this region, but the associated rainfall is not as abundant as precipitation caused by deep convective clouds. It is also seen that a strong signal of shallow convective clouds modulates rainfall over the coastal areas of Northeast of Brazil and adjacent ocean. In this scenario, the main objective of this study is to contribute to a better understanding of the patterns of cloud types associated with precipitation and building a climatological analysis from the classification of clouds.
\end{abstract}

\section{Introduction}

The Northeast Region of Brazil (NEB), characterized as a semiarid region, presents scarce rainfall and is frequently affected by long periods of drought $[1,2]$. The annual accumulated precipitation does not exceed $500 \mathrm{~mm}$ in some areas of the semiarid Northeast; in contrast, there are areas like the coastland of the NEB where the annual rainfall is more than $1500 \mathrm{~mm}$ [3-6]. There are cases of significant rainfall, causing floods, flooding, and landslides in vulnerable areas, leading to economic and life losses. Reference [7] suggests that climate changes and human interference can result in more heavy rainfall events. These significant events can be caused by disturbances in other systems patterns known as the Intertropical Convergence Zone (ITCZ) [8], Upper Tropospheric Cyclonic Vortex (VCAN) [9], disturbances in the trade winds [10], squall lines [11], front systems in southern of NEB [12], and South Atlantic Convergence Zone (SACZ) [13].

Covering around $18 \%$ of Brazilian territory, NEB is situated between $1^{\circ} \mathrm{N}$ and $18^{\circ} \mathrm{S}$ and $34.5^{\circ} \mathrm{W}$ and $48.5^{\circ} \mathrm{W}$. Due to this great extension and variability of rainfall it is of paramount importance that the particularities of each subregion are considered. The subregion further north for example is more common in the presence of ITCZ that is characterized by a band of convective cloud cover that surrounds the equatorial region. The positioning of this convergence zone is extremely important for the characteristics of the rainy season in the northern sector of Northeast Brazil.

Another important system for precipitation over the northern region of Northeast Brazil is squall lines, which according to $[14,15]$ are formed on average over an area which extends from Surinam to the Brazilian state of Maranhão, and in El-Niño years they form further north and La-Niña years further south.

In the interior area of $\mathrm{NEB}$ can observe various weather systems; among them is the ITCZ and VCAN. The VCANs are characterized by downward movements in the center of the vortex and upward movements in its periphery, where the cold, dry air in the center inhibits cloud formation and the hot and humid air on the edge favors it [16]. Many studies show that most VCAN cases are observed during summer and are more frequent in January $[9,17-21]$. 
Another extremely important system to the east of Northeast Brazil is the easterly waves which were first studied by [10], which noted that there were changes in wind direction during the formation and displacement of the pressure centers in the tropics and that these centers could be the result of waves propagating in the atmosphere from east to west. Reference [22] identified easterly waves in the Tropical South Atlantic Ocean spreading toward the coastline of Northeast of Brazil more often during the months of June, July, and August in the eastern sector of Northeast Brazil, suggesting that the rainy season in this sector would be modulated by easterly waves.

In the case of Northeastern Brazil, it is assumed that most precipitation is caused by low clouds with relatively warm tops [23], due to subsidence in the area associated with the Walker cell. Precipitation estimation from satellite data is typically achieved through algorithms which use information from spectral bands in the visible, infrared, and microwave spectra.

The different techniques using visible and infrared spectra enable analyzing only the cloud tops (brightness and temperature) and thus are a limiting factor for precipitation estimates [24]. References $[25,26]$ found that techniques using infrared and passive microwave radiation are not very effective for estimate precipitation in NEB, in view of the predominance of shallow clouds with relatively warm tops in this region.

Approximately $50 \%$ of precipitating clouds in the Northeast do not contain ice in their structure [26], and these clouds are not efficiently detected by passive microwave sensors which utilize a radiation scattering technique to estimate precipitation. These techniques underestimate rain because it takes place in shallow and stratiform cloud systems, where the amount of ice inside the cloud is very small (and sometimes, no ice is present). Techniques using active microwave sensors are more effective and generate better results for this region, because active microwave techniques have an additional advantage as they can penetrate clouds [27].

In this scenario, the research was aimed at using active microwave sensor retrieval techniques in order to contribute to a better understanding of the types of clouds present in $\mathrm{NEB}$, as well as their characteristics, frequency with which they occur, and the impact on rainfall in the region. A period of 15 years (from 1998 to 2012) of TRMM (Tropical Rainfall Measuring Mission) satellite data was analyzed, from a climatological point of view. To avoid the shortcomings mentioned above, this study utilizes data from the Precipitation Radar (PR) on board the TRMM satellite, which contains an active microwave sensor, a good tool to diagnose precipitation characteristics in the tropics.

\section{Data and Methods}

Encompassing a fairly wide region, the Brazilian Northeast has different climatic conditions which are directly related to the amount of precipitation observed in each area. In the present investigation, the Northeast Region of Brazil was divided into four subregions A1, A2, A3, and A4 (Figure 1). This division was made taking into account the rainfall regime and prevalence of weather systems. Area A1, comprising the north of the states of Maranhão (MA), Piauí $(\mathrm{PI})$, and Ceará (CE). The most common phenomena in this region are the Intertropical Convergence Zone, squall lines, moisture convergence (breezes and trade winds), and local convection; Area A2 comprises part of the states Maranhão (MA), Piauí (PI), Ceará (CE), Paraíba (PB), Pernambuco $(\mathrm{PE})$, and Bahia (BA). This region is characterized by low values of accumulated precipitation, essentially from the remains of systems which occur in the $\mathrm{A} 1, \mathrm{~A} 2$, and $\mathrm{A} 3$ areas and can influence this region; Area A3 comprises the states of Rio Grande do Norte (RN), Paraíba (PA), Pernambuco $(\mathrm{PE})$, Alagoas (AL), and Sergipe (SE). This region is characterized by moisture convergence of trade winds, easterly waves, and breezes associated with topography and humidity convergence; Area A4 comprises much of the Bahia state. This region is influenced by the presence of the South Atlantic Convergence Zone, frontal systems, local convection, and breezes.

2.1. Data-PR/TRMM. The $\mathrm{PR}$ sensor is a rainfall radar that operates at a frequency of $13.8 \mathrm{GHz}$ (K-Band) with a minimum sensitivity of $17 \mathrm{dBZ}$, a vertical resolution of $250 \mathrm{~m}$, a horizontal resolution of $5 \mathrm{~km}$, and a temporal frequency of 16 orbits per day [28]. In the present study, we used a series of 15 years (1998-2012) of PR/TRMM data with the goal of identifying the patterns of precipitating clouds from a climatological point of view, using the vertical profile of rain. To this, we employed the Rain Type Flag classification of the 2A25 product, version 7. NASA provides PR/TRMM data from the end of 1997 to October 07 2014, when TRMM radar sensor activities were shut down.

2.2. Classification of Precipitating Clouds from the Vertical Profile of Rain. The vertical rain profile is deduced with a hybrid of the Hitschfeld-Bordan method [29]. The rain type classification is based on the strength, vertical profile, and horizontal extent of the precipitation systems, categorised mainly as stratiform and convective. The other category refers to noise or regions of no precipitation near the surface and was therefore not considered in this work. These methods were subsequently modified by [30], who investigated the rainfall processes and isolated shallow convection and formulated a new classification known as the 2A23 algorithm. According to the authors, stratiform rain could previously be confused with warm rain produced by shallow convection; therefore warm rain processes are classified as convective in the new classification.

This work used the new version of the classification, in which only the precipitating clouds with rainfall amounts greater than zero at the surface were considered, classified as stratiform and convective. Data of each satellite passing over the study region were extracted and were separated into one of three groups following this classification:

(i) Stratiform precipitation characterized by Bright Band and reflectivity $\left(Z_{\max }\right)<40 \mathrm{dBz}$

(ii) Shallow convective precipitation characterized by reflectivity $\left(Z_{\max }\right)>40 \mathrm{dBz}$ and cloud top temperature $>0^{\circ} \mathrm{C}$ 


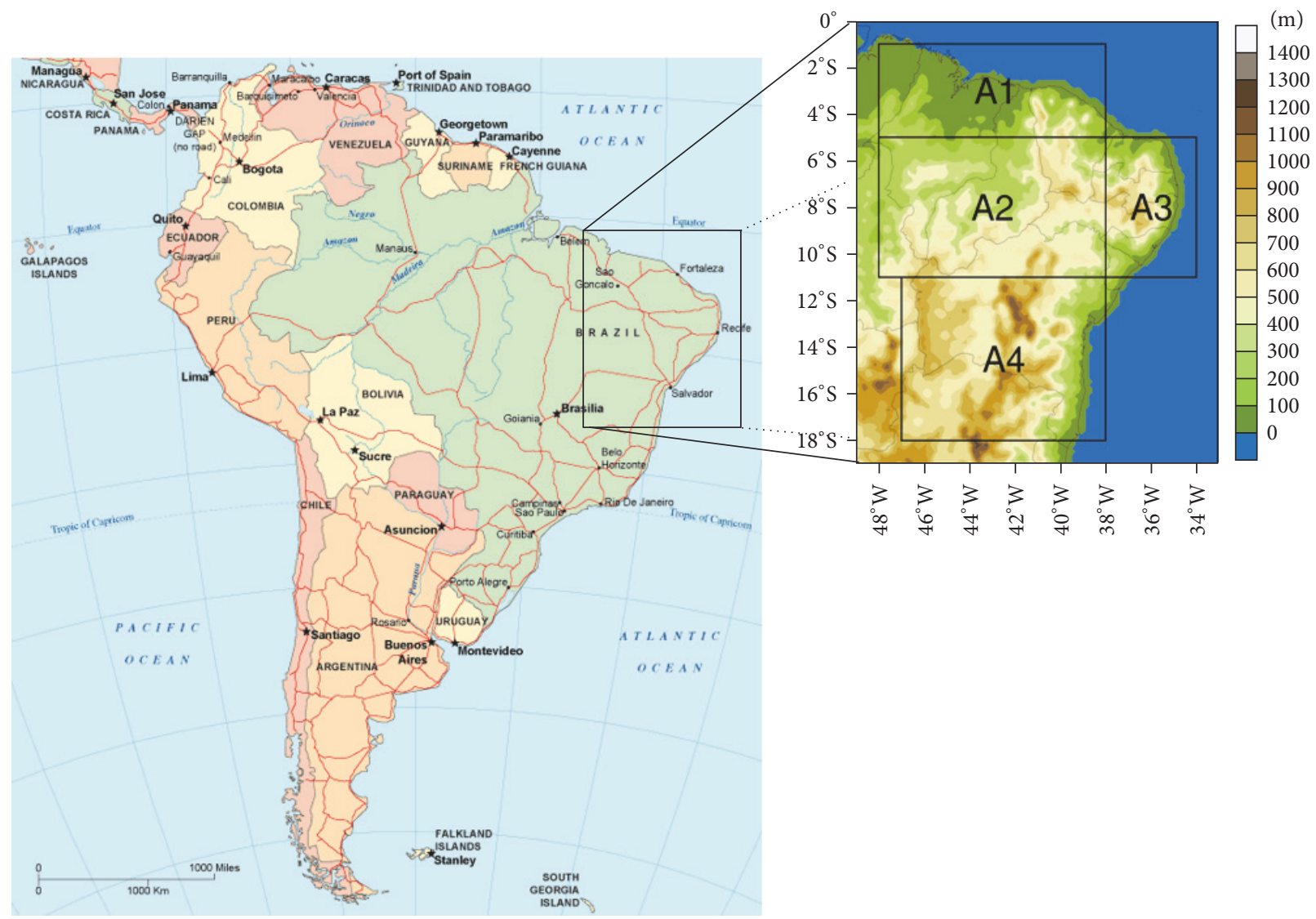

Figure 1: Map of South America with emphasis on Northeast Brazil. The demarcated areas are A1: northern, A2: inside, A3: eastern, and A4: southern, corresponding to the subregions adopted in this study.

(iii) Deep convective precipitation characterized by reflectivity $\left(Z_{\max }\right)>40 \mathrm{dBz}$ and cloud top temperature $<$ $0^{\circ} \mathrm{C}$

$Z_{\max }$ is the maximum of $Z$ along the range for each antenna scan angle below freezing level.

\section{Results and Discussion}

3.1. Annual Cycle of Precipitating Clouds in Northeast Brazil. Understanding of the precipitating clouds in the tropics is still incomplete. Observing the annual cycle of these clouds can help to understand their physical processes and identify a climatological pattern.

According to Figure 2(a), it can be observed that, in the $\mathrm{Al}$ area (northern), the fraction of occurrence of deep convective storms varies between $10 \%$ and $18 \%$ throughout the year. Shallow convection has a higher frequency in the winter months with a maximum of occurrence of $\approx 70 \%$ in August. Rain of the stratiform type is more abundant from December to April with a trend of decreasing frequency in winter. As it is shown in Figure 2(b), the number of events is greater during the months of January to May, where intense ITCZ and squall lines systems occur. Importantly, even if the relative maximum of shallow convection occurs between July and September, the total number of events is much smaller than in the months of January to May. One can also note that on average the fraction of precipitating clouds with a vertical profile of shallow convective rain is greater, occurring in $47.3 \%$ of events; however, the rainfall amount during the months of the highest occurrence of shallow convection is climatologically small.

Figure 2(c) shows the A2 area (inside) with a pattern of significant increase in the occurrence of shallow convective rain clouds from May to September with a maximum value of $\approx 80 \%$, along with a decrease in the occurrence of stratiform and deep convective rain in these same months. One hypothesis for this result would be that the winter circulation pattern is perhaps related to the Hadley and Walker cells, inhibiting deep convection and favoring shallow convection. Noteworthy is the month of July which shows minimum values of $\approx 5 \%$ to $\approx 20 \%$ for stratiform and deep convective clouds, respectively. It is noted that throughout the year the occurrence of deep convection is around $20 \%$ and the maximum of shallow convection occurs during winter, while clouds with stratiform rainfall profiles occur more frequently in other seasons. However, Figure 2(d) shows a decrease in the average number of events during winter. It can be noted that the pattern of the number of events is similar to that of the Al region, being displaced to the winter months.

According to Figures 2(e) and 2(f), the A3 area (eastern) was dominated by shallow convective rain throughout 
the annual cycle. Relative frequency ranged from $45 \%$ (February) to $95 \%$ (August), with a peak in the months between July and November. This may be related to easterly waves which are longer and faster during this period of the year, according to [31-33]. This period is commonly associated with the occurrence of landslides and flooding over the states of Alagoas and Paraiba.

In the $\mathrm{A} 4$ area (south), it is noticed that during the winter there is a predominance of shallow convection $(\approx 90 \%)$, with a behavior similar to that of the A2 area (inside), as can be seen in Figure 2(g). Some of the Bahia coastline areas, mainly Salvador, present cases of flooding and significant accumulated rainfall during this period, according to the climanálise newsletter [19]. Between the months of October and March, precipitating clouds with stratiform vertical rain profile are more common $(\approx 60 \%)$. With respect to deep convection, the influence is small as it occurs in approximately $10 \%$ of cases throughout the annual cycle. Regarding the number of events (Figure 2(h)) the months of November to March recorded the highest number of events, which can be directly related to large-scale events such as South Atlantic Convergence Zone (SACZ) events, for example. The SACZ has been subjectively defined as an elongated convective band typically originating in the Amazon basin, extending toward southeast Brazil and protruding into the southeastern subtropical Atlantic Ocean $[13,34-36]$.

In order to characterize the average behavior of precipitating clouds in Northeastern Brazil using radar data on board the TRMM satellite, the spatial distribution of the number of events of each cloud type, the relative frequency of occurrence of each cloud type, and the fraction of the rainfall volume associated with each cloud type were analyzed. Average monthly maps were constructed considering the full period of 15 years considered (1998-2012).

Figure 3 illustrates the total number of events for the months from January to December. It is first noted that between 0 and 10000 events have been recorded during the study period over the study area for each grid point.

It can be observed that in January, February, and March (Figures 3(a)-3(c)) the occurrence of precipitating cloud events is higher in the western portion of the Northeast Region of Brazil, mainly affecting the states of Maranhão, Piauí, and western Bahia. Over the ocean, the number of events is generally smaller, concentrating the highest values on the equatorial portion of the Atlantic Ocean, especially during the month of March. Perhaps this behavior is related to squall lines and the ITCZ.

The months of April and May also show an increased number of precipitating cloud events over the equatorial expanse of the Atlantic Ocean, but also in the northern area of the Northeast Region (Figures 3(d) and 3(e)). This can be justified both by thermodynamics and by the dynamics of weather systems responsible for the rainy season in these regions, such as the ITCZ [37] being displaced southerly of its climatology position in the months of February to May, due primarily to an increase in sea surface temperature. The equatorial trough, convergence of the trade winds, and maximum moisture convergence also occur during this period. These combined factors contribute to the elevation of many air parcels and thus form clouds with strong rainfall potential, which are responsible for the rainy season in northern Northeast Brazil.

During June (Figure 3(f)), July, and August (Figures 4(a) and $4(\mathrm{~b}))$, the pattern is very different from the previous months. Over the continent the number of events is small and over the ocean merely the coastal areas have the highest values, especially for the month of June. This can be directly related to easterly waves.

The month of September is characterized by a few events of precipitating clouds, both on the continent and over the ocean (Figure 4(c)). The months of October, November, and December (Figures 4(d)-4(f)) have a very small occurrence of events over the ocean. However, over the continent high values are observed towards the southwest of the Northeast Region of Brazil, affecting mainly the states of Bahia, southern Piauí, and southern Maranhão with a peak in December. These results have a relation between the fact that the South Atlantic Convergence Zone is displaced eastward in December as described by [38].

The results presented regarding the number of events is physically coherent, taking into consideration that the largescale atmospheric circulation is modulated by the Walker and Hadley cells. The Hadley cell is responsible for the transport of heat by convection from the equatorial region to the midlatitudes, thus forming one of the main precipitation systems influencing the precipitation regime in northern Northeast Brazil which is the ITCZ. In contrast, during drier periods the descending branch of the Walker cell inhibits the formation of clouds with great vertical development and favors clouds with horizontal development, which is the case of stratiform clouds or shallow convective clouds. Thus, the atmospheric circulation pattern also explains the fact that stratiform and shallow convective clouds occur more frequently than deep convective clouds.

Figures 5, 6, and 7 show the relative frequency of events (a) and the fraction of the precipitation rate (b) for each type of precipitating clouds during the months of March, June, and November. The results for other months have similar characteristics and are illustrated in the first author's Master's thesis [39].

Comparing the results of the relative frequency of the precipitating cloud events to the fraction of rainfall corresponding to each type of cloud (Figures 5, 6, and 7), it can be observed that during the considered period the occurrence of deep convective clouds is small but the rainfall generated by this type of cloud is very significant, on average responsible for over $60 \%$ of the precipitation occurring in the region. From the calculation of the average rainfall for each subregion, average values of approximately $12.0 \mathrm{~mm} / \mathrm{h}$, $2.5 \mathrm{~mm} / \mathrm{h}$ and $2.5 \mathrm{~mm} / \mathrm{h}$ were attributed to the deep and shallow convective clouds and stratiform clouds, respectively. These values can explain the fact that few deep convective cloud events can contribute to more than $60 \%$ of total rainfall. The frequency of occurrence of shallow convective clouds is almost $80 \%$ throughout the year and is higher over the ocean and coastal areas, which can be seen in the Figures 5, 6, and 7. The months March, June, and November were chosen because they are more representative among others months. 


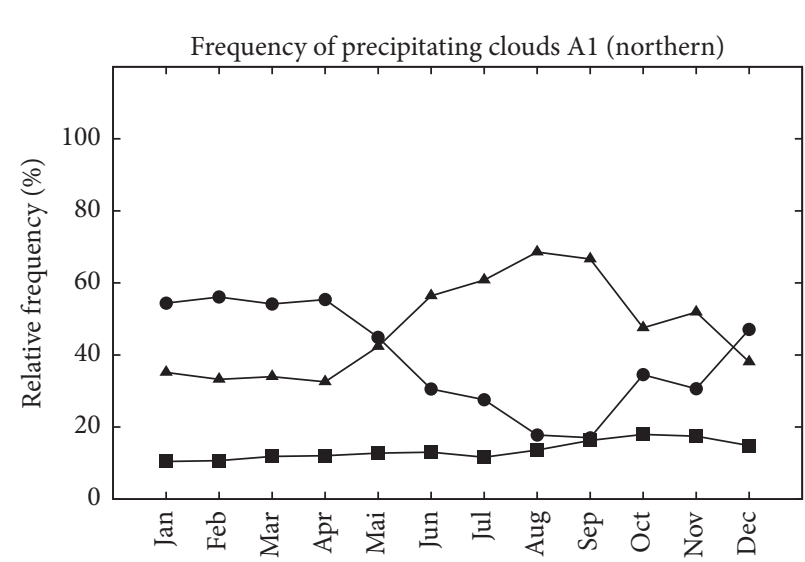

(1998-2012)

$\rightarrow$ Stratiform

-- Deep convection

$\_$Shallow convection

(a)

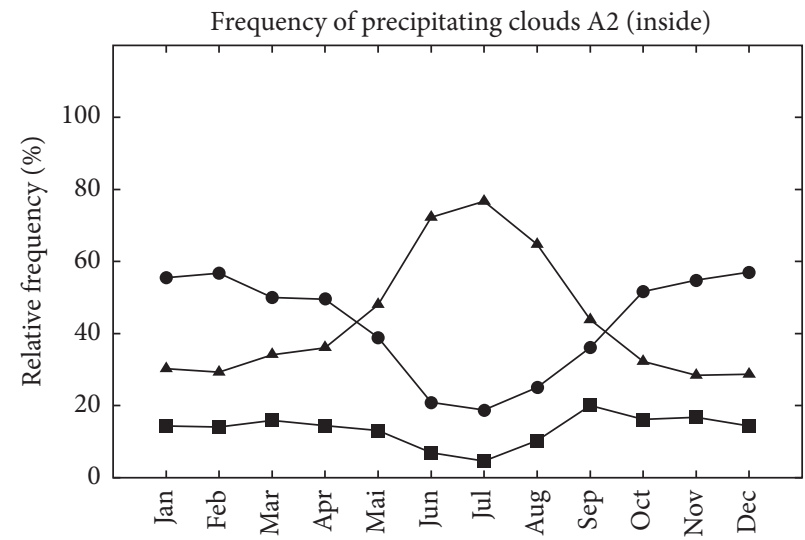

(1998-2012)

$\rightarrow$ Stratiform

$\rightarrow$ Deep convection

$\_$Shallow convection

(c)

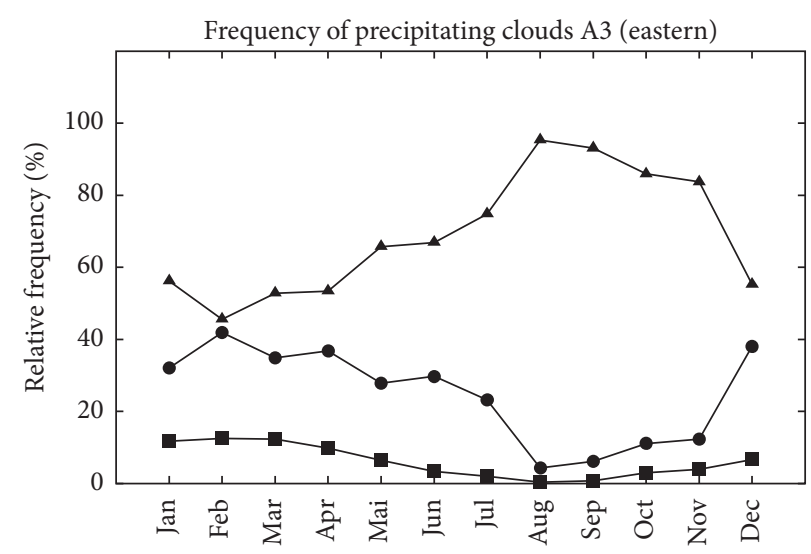

(1998-2012)

- Stratiform

- Deep convection

$\_$Shallow convection

(e)

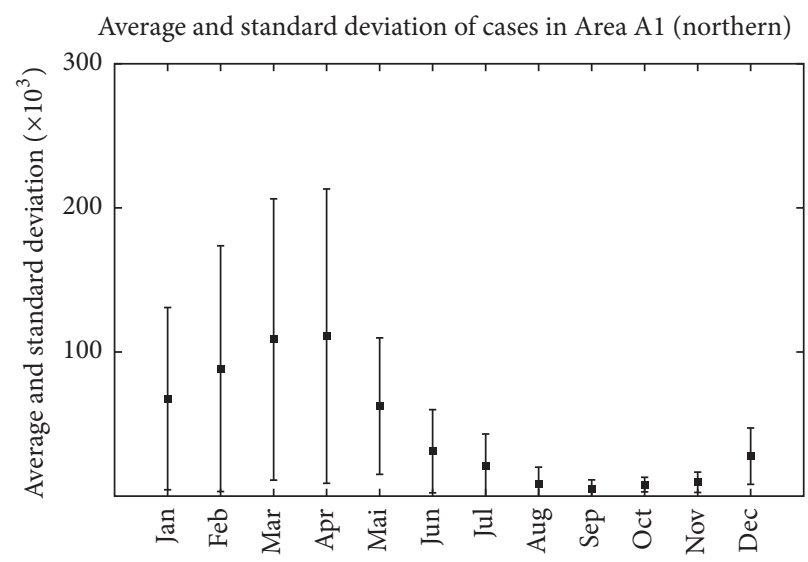

(1998-2012)

(b)

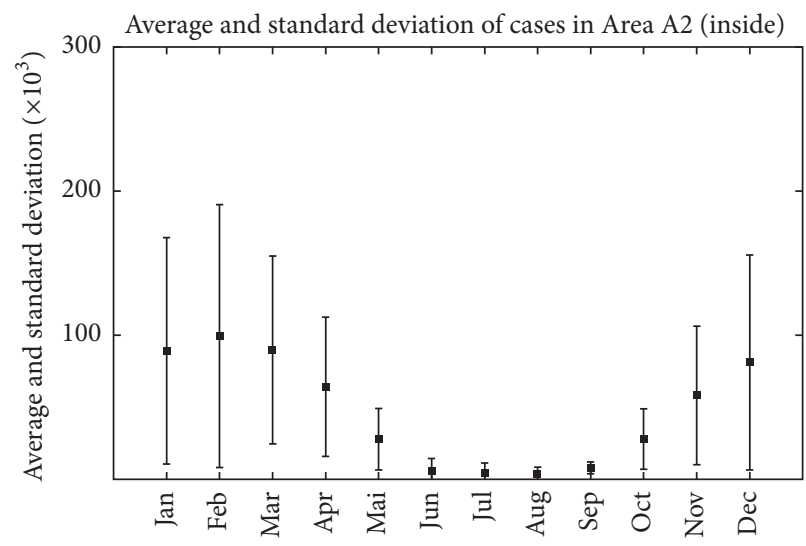

(1998-2012)

(d)

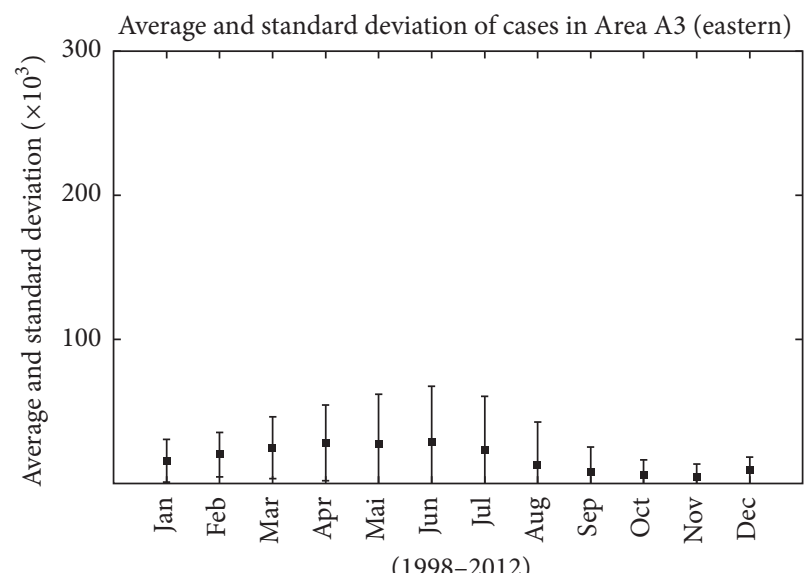

(1998-2012) 


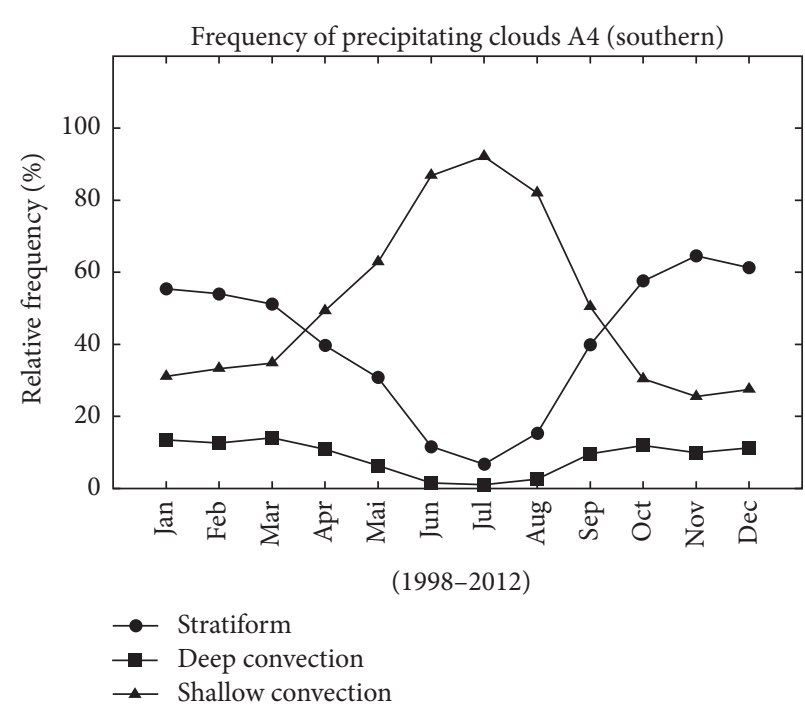

(g)

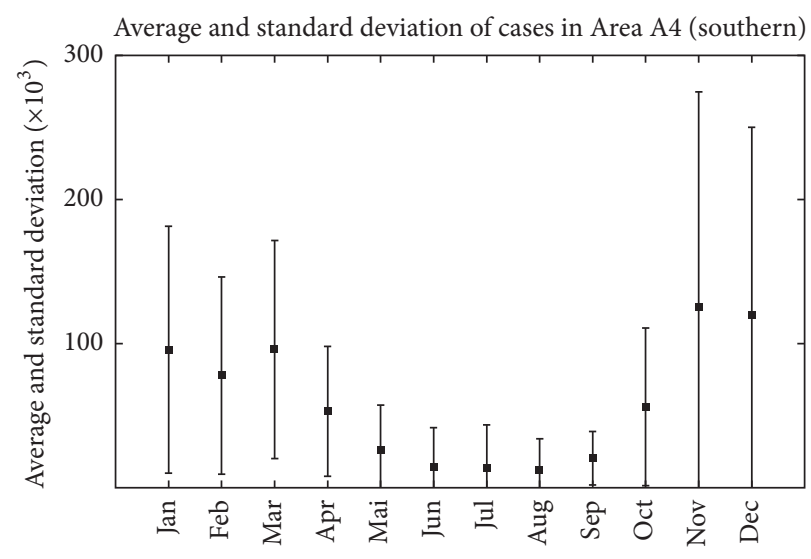

(1998-2012)

(h)

FIGURE 2: Relative frequency of precipitating clouds to the A1: northern, A2: inside, A3: eastern, and A4: southern areas of Northeast Brazil. Mean and standard deviation of the number of events.

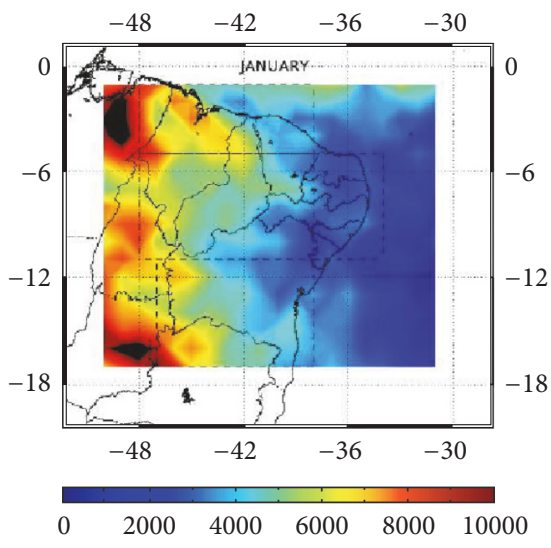

Amount of events occurring (1998-2012)

(a)

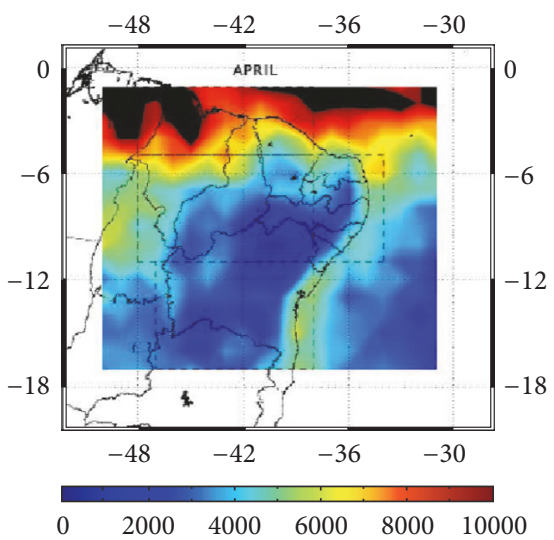

Amount of events occurring (1998-2012)

(d)

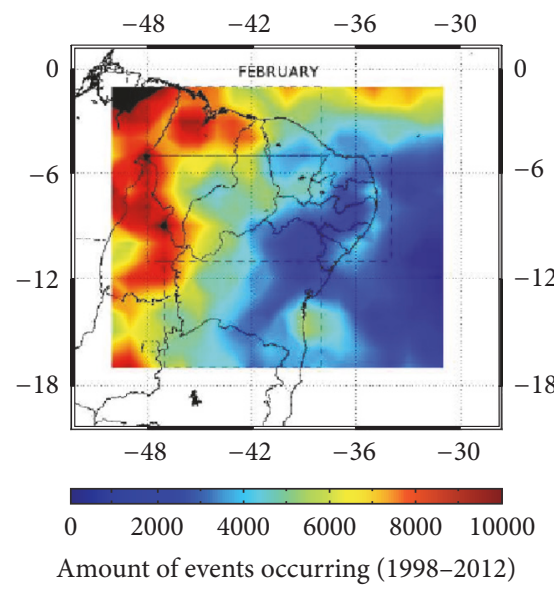

(b)

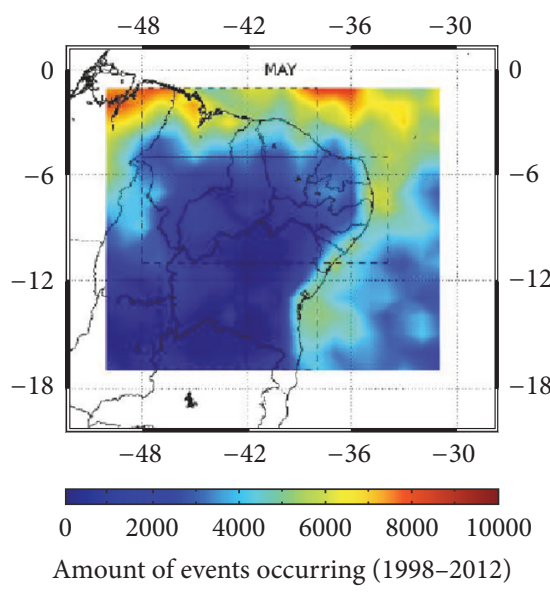

(e)

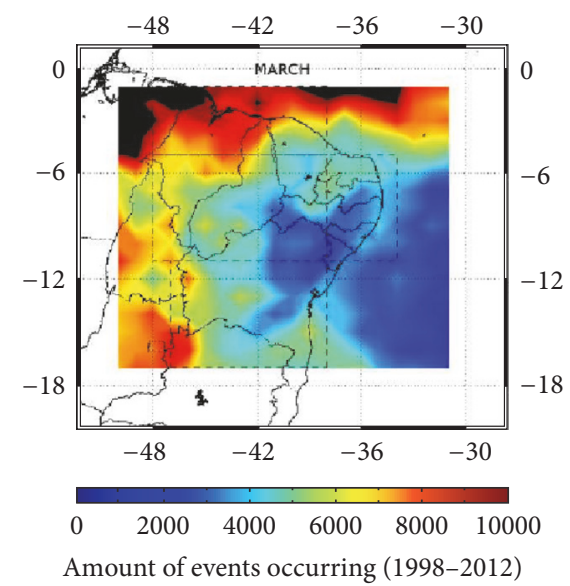

(c)

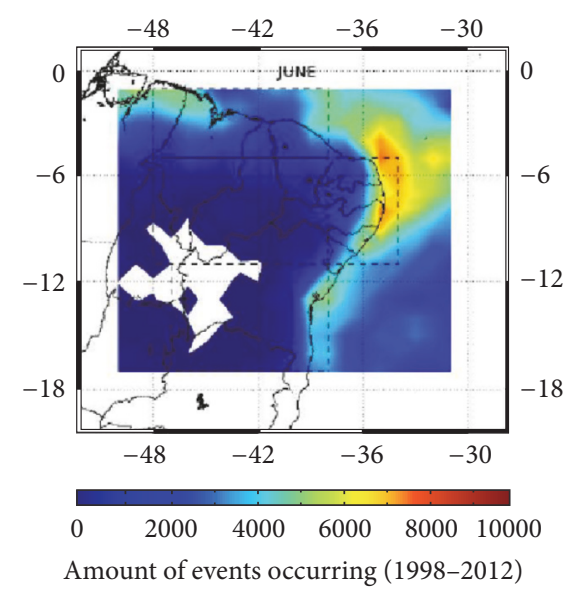

(f)

FIGURE 3: Spatial representation of the number of events for the months of January to June. 


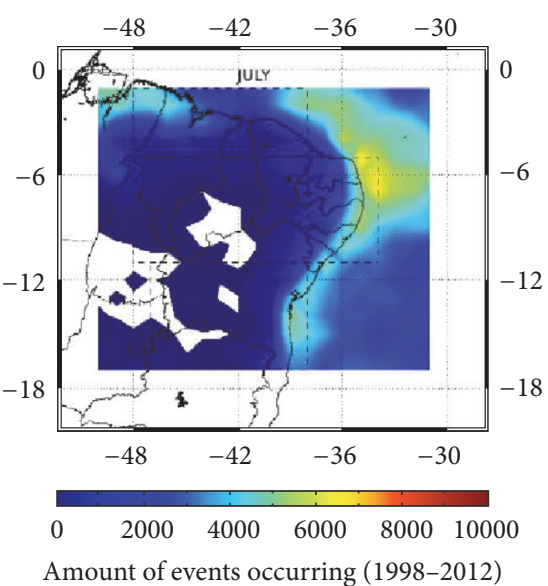

(a)

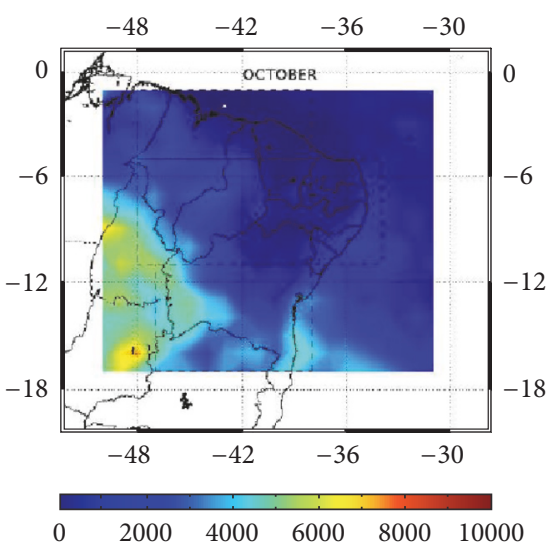

Amount of events occurring (1998-2012)

(d)

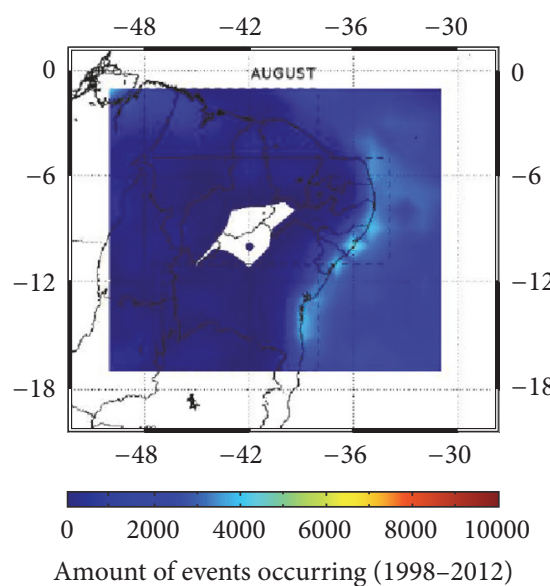

(b)

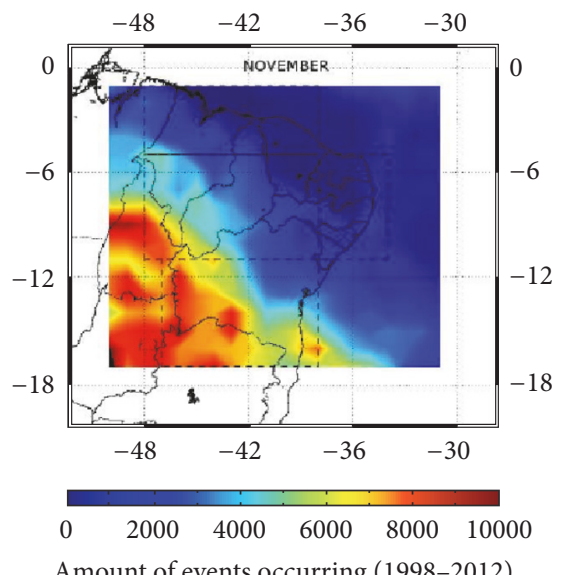

(e)

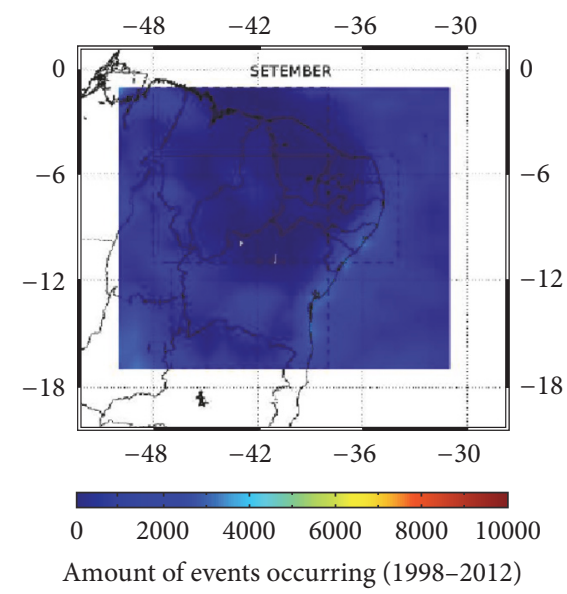

(c)

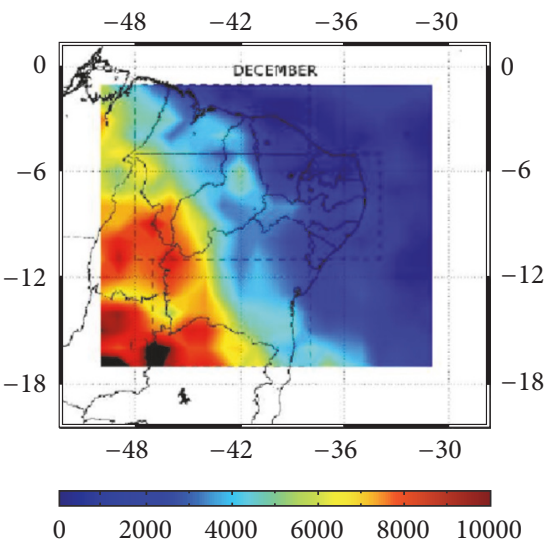

Amount of events occurring (1998-2012)

(f)

FIGURE 4: Spatial representation of the number of events for the months of July to December.

As for the stratiform clouds, it can be observed that they occur quite frequently in Northeast Brazil though the rainfall amount associated with them is small. From June to October the occurrence and total precipitation fractions of these clouds are very similar. For example, in June approximately $30 \%$ of stratiform cloud events correspond to a precipitation fraction of nearly $30 \%$, while in March the occurrence of events is about $10 \%$, which corresponds to a precipitation fraction of about $60 \%$, as shown in Figures 6 (June) and 5 (March).

It can be observed that there is a consistent relationship between the relative frequency of events and the rainfall contribution (fraction) of each type of precipitating cloud, with the seasonal patterns of precipitating systems in each area defined in this study.

The Al area, corresponding to the northern portion of Northeast Brazil, has a rainy season from January to June, with higher accumulated precipitation in the months of March and April due to the strong influence of the ITCZ which is located south of its climatological position [37, 40]. In this research we evaluated which cloud types occur more frequently during the months which this system is positioned further south (Figures 3(c) and 3(d)). We also analyzed the contribution of each type of cloud to the total precipitation amount using PR/TRMM data. Thus, it was found that in the months of March-April, stratiform clouds occur at a higher frequency $(60 \%)$ while deep convective clouds only occur in about $10 \%$ of cases. However, the precipitation amount associated with stratiform clouds is small, while the deep convective clouds are responsible for a large amount of precipitation. Another interesting result is that about $60 \%$ of the total rainfall originates from deep convective clouds during those months, from which it can be inferred when weather systems are positioned over this region (e.g., a southerly displaced ITCZ). The band of cloud cover over northern of Northeast Brazil is largely composed of stratiform clouds, but the deep convective clouds present in a smaller amount cause a much greater impact on rainfall amount in this sector. This was already expected, showing that the results are consistent.

In Area A2, corresponding to area of the interior of Northeast Brazil, the influence of various weather systems can be observed. Among them is the ITCZ which is well marked over northern Northeast Brazil (as previously reported) but also interferes with precipitation over the states north of the A2 area. Another important system for the interior of Northeast Brazil is VCANs which form over the South 


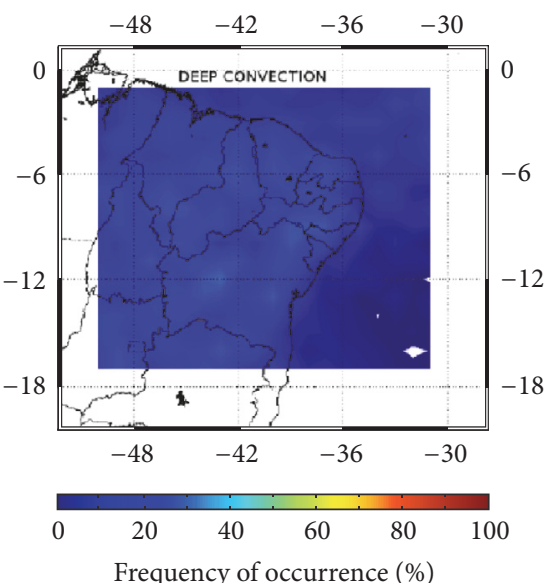

Frequency of occurrence $(\%)$

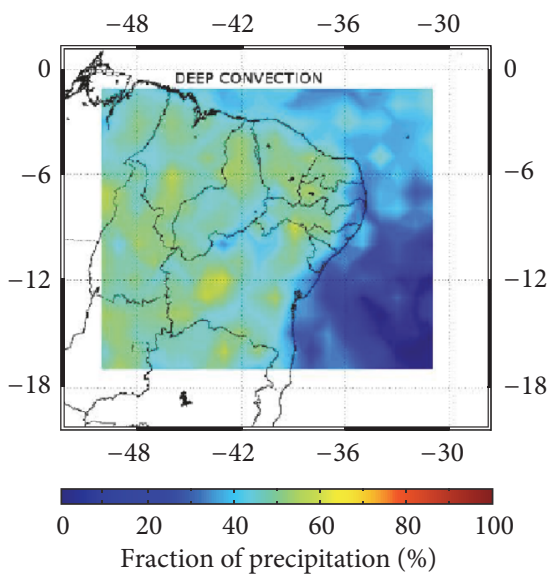

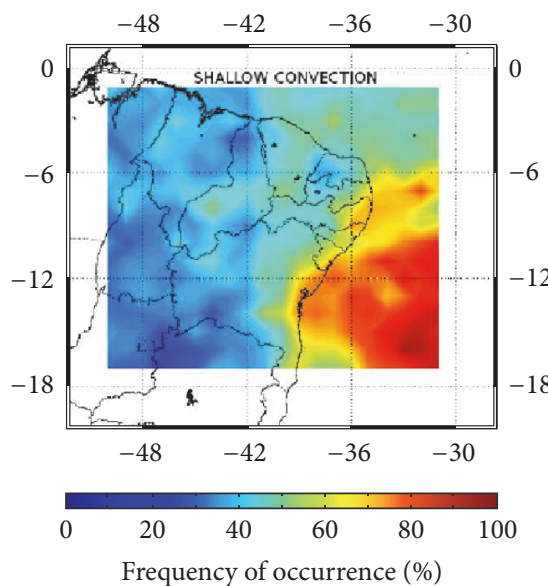

(a)
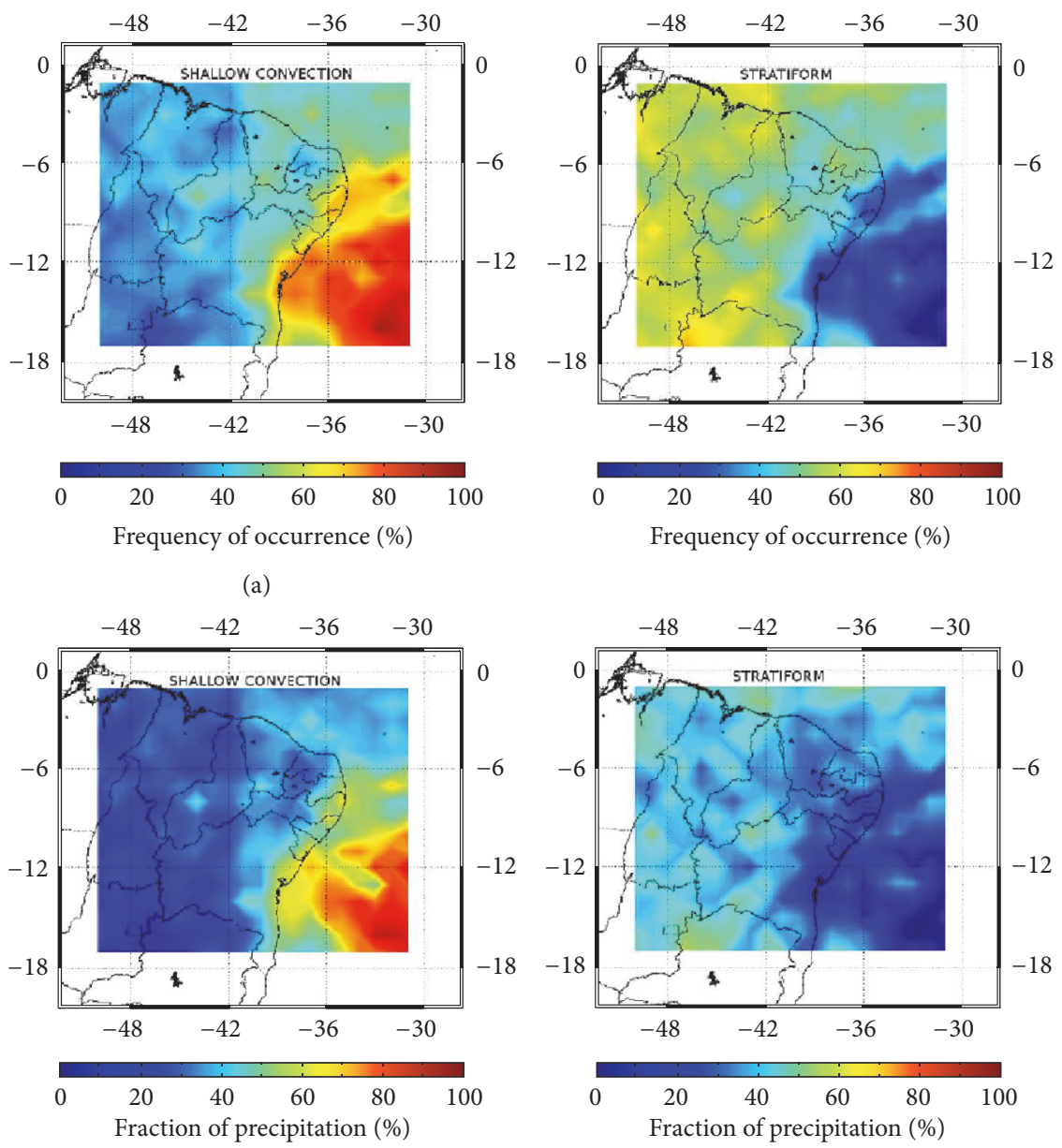

(b)

FIGURE 5: Relative frequency of events by cloud type (a) and fraction of precipitation explained by each cloud type contributing to total precipitation (b), for the month of March.

Atlantic Ocean and have an impact near the coast of Northeast Brazil. Analyzing the results obtained for the month of January, it was revealed that, in this sector of Northeast Brazil, deep convective clouds occur in about $20 \%$ of events and that stratiform clouds occur in about $60 \%$. With respect to precipitation from the point of view of the PR/TRMM sensor, we note that precipitation is more significant due to deep convective clouds, which represent about $60 \%$ of all precipitation for this sector, followed by precipitation from stratiform clouds at about $30 \%$. Therefore, systems such as the ITCZ and VCANs may show cloudiness with a higher occurrence of precipitating clouds with stratiform vertical rain profiles, but further studies on the classification of cloud types are required to make a definite statement.

In the $\mathrm{A} 3$ area, corresponding to eastern Northeast Brazil, the presence of VCANs is also observed; however, their influence depends largely on the location of the center of the vortex. Figure 5 illustrates that $60 \%$ of the precipitation is due to deep convection from northern Rio Grande do Norte to northern Sergipe in the month of March. However, over the coastal areas of these states, about $80 \%$ of precipitation is due to shallow convective clouds, which can be explained by the fact that the centers of the classic VCANs are climatologically positioned over the ocean. A hypothesis is that the center of the vortex would be composed of shallow convection clouds.

In this work it was brought to light that during the JJA quarter there is a significant presence of shallow convective clouds over the whole coastline of Northeast Brazil. Rainfall from deep convective clouds is very significant, but their occurrence is very small in this sector and this period is dominated by shallow convective clouds, followed by stratiform clouds. Thus it can be inferred that the cloudiness near the east coast of Northeast Brazil generated by easterly waves consists mainly of shallow convective clouds. Winds perpendicular to the coast increase the convergence of moisture flux, favoring the formation of clouds on the coast of Northeast Brazil.

In the A4 area corresponding to southern Northeast Brazil, the main rainy season occurs during the months of November, December, and January, with maximum rainfall in December [41]. The South Atlantic Convergence Zone is one of the main systems that can influence precipitation over this region and, according to [38], the month of December is the period in which this system is positioned further east. This 


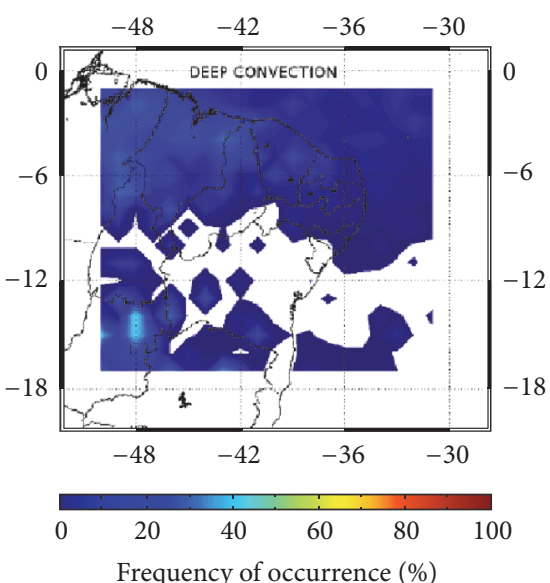

Frequency of occurrence (\%)

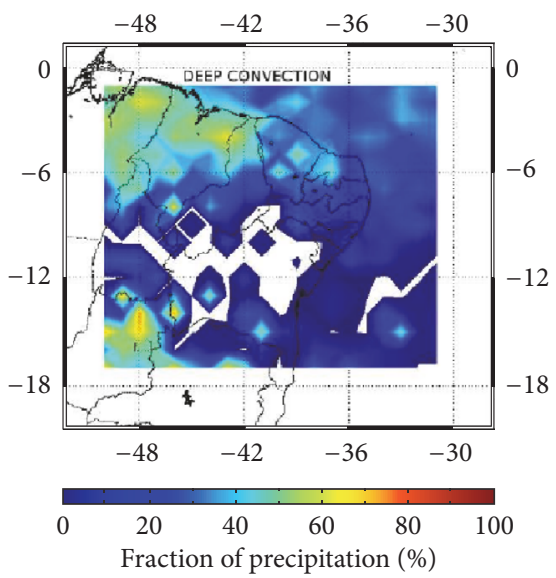

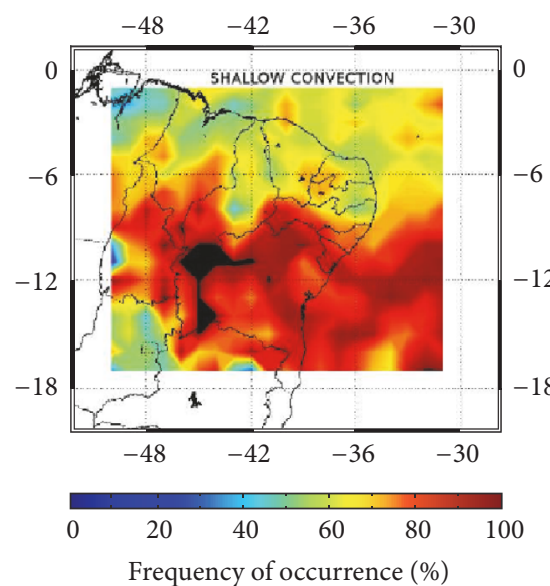

(a)
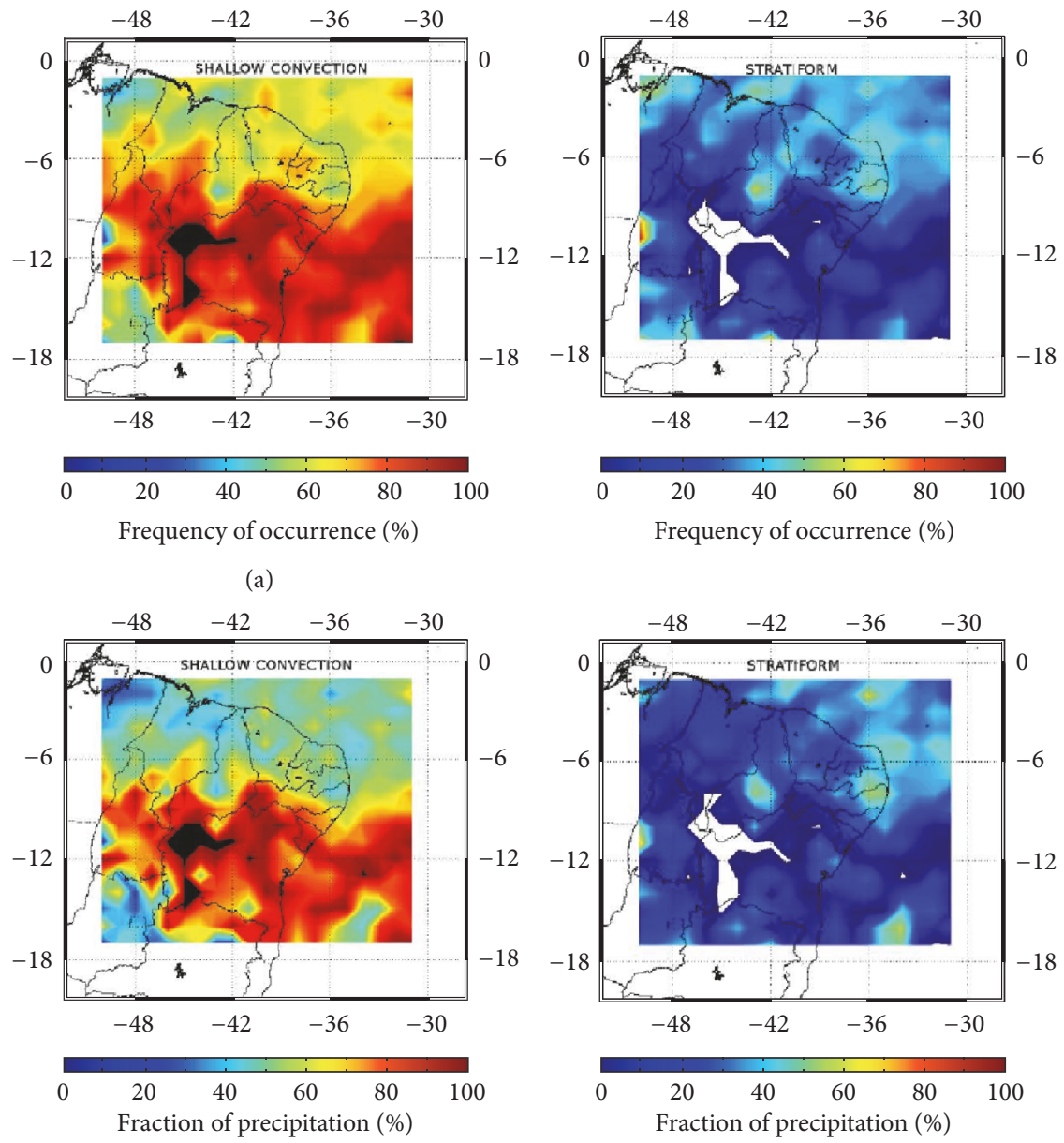

(b)

FIGURE 6: Relative frequency of events by cloud type (a) and fraction of precipitation explained by each cloud type contributing to total precipitation (b), for the month of June.

favors cloudiness over southern Northeast Brazil which is, from the perspective of PR/TRMM, predominantly formed by stratiform clouds, as shown in Figure 7. However, it is also possible to identify a few precipitating clouds with deep convective vertical rain profile during this period, which are more significant in terms of rainfall. The autumn and winter periods in southern Northeast Brazil are marked by the presence of frontal systems which can reach lower latitudes [12], or remnants of these systems. In this work we observed that in the fall and winter periods there is a predominance of shallow convective clouds that have a frequency of occurrence of about $80 \%$ compared to the stratiform and deep convective clouds.

In Figures 5, 6, and 7, a progression of shallow convection from the ocean to the continent is observed throughout the year, more obviously between the months of April to September, with a high frequency and a high fraction of associated precipitation. One hypothesis for this behavior would be the great influence of easterly waves associated with the subtropical high over the South Atlantic shifted northwards, favoring moisture transport from the ocean to the mainland. Other systems such as instability lines of moderate or weak intensity and the land/sea breeze circulation could also explain this progression of shallow convection.

\section{Summary and Conclusions}

In the present investigation a time series of 15 years of PR/TRMM satellite data was analyzed in order to obtain a better understanding of the cloud types associated with precipitation in Northeast Region of Brazil. From the results, we conclude that it is possible to obtain the average behavior of precipitating clouds in Northeast Brazil using satellite/radar data. With TRMM-PR-2A23 product that classifies precipitation it was possible to identify precipitating clouds according to their vertical precipitation profile as stratiform, shallow, and deep convective and also identify the frequency of occurrence of each type.

The results show that over land the occurrence of clouds with stratiform vertical rainfall profile is higher, but the average rate of precipitation associated with this kind of cloud is small. In contrast, deep convective clouds have a small relative occurrence over the continent, but their associated average precipitation rate is significant. Over the adjacent 


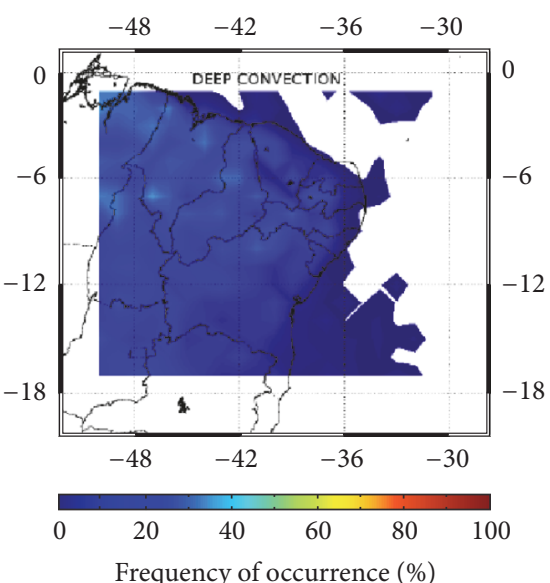

Frequency of occurrence (\%)

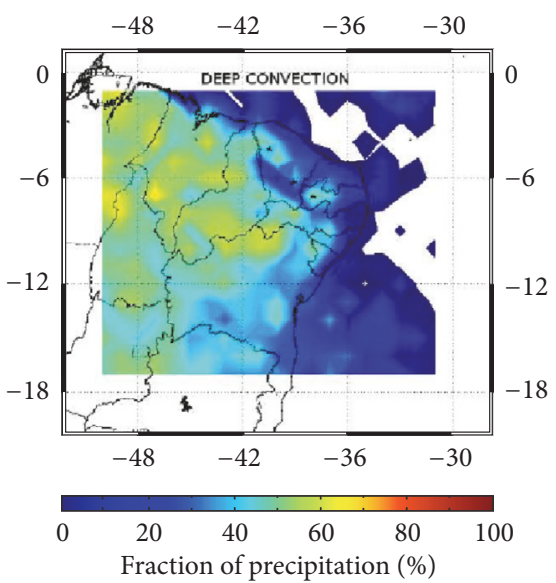

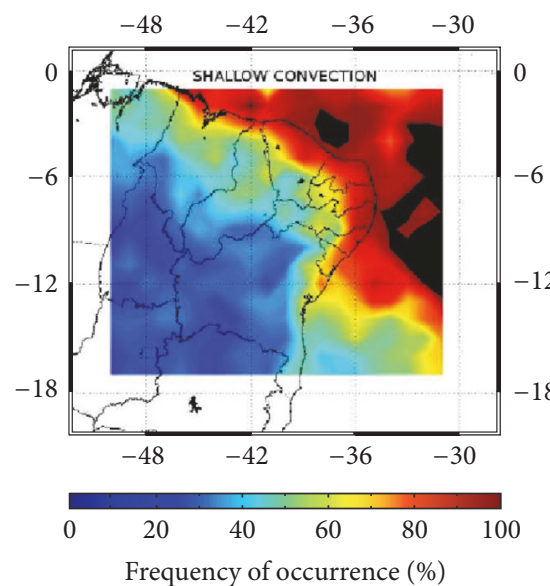

(a)
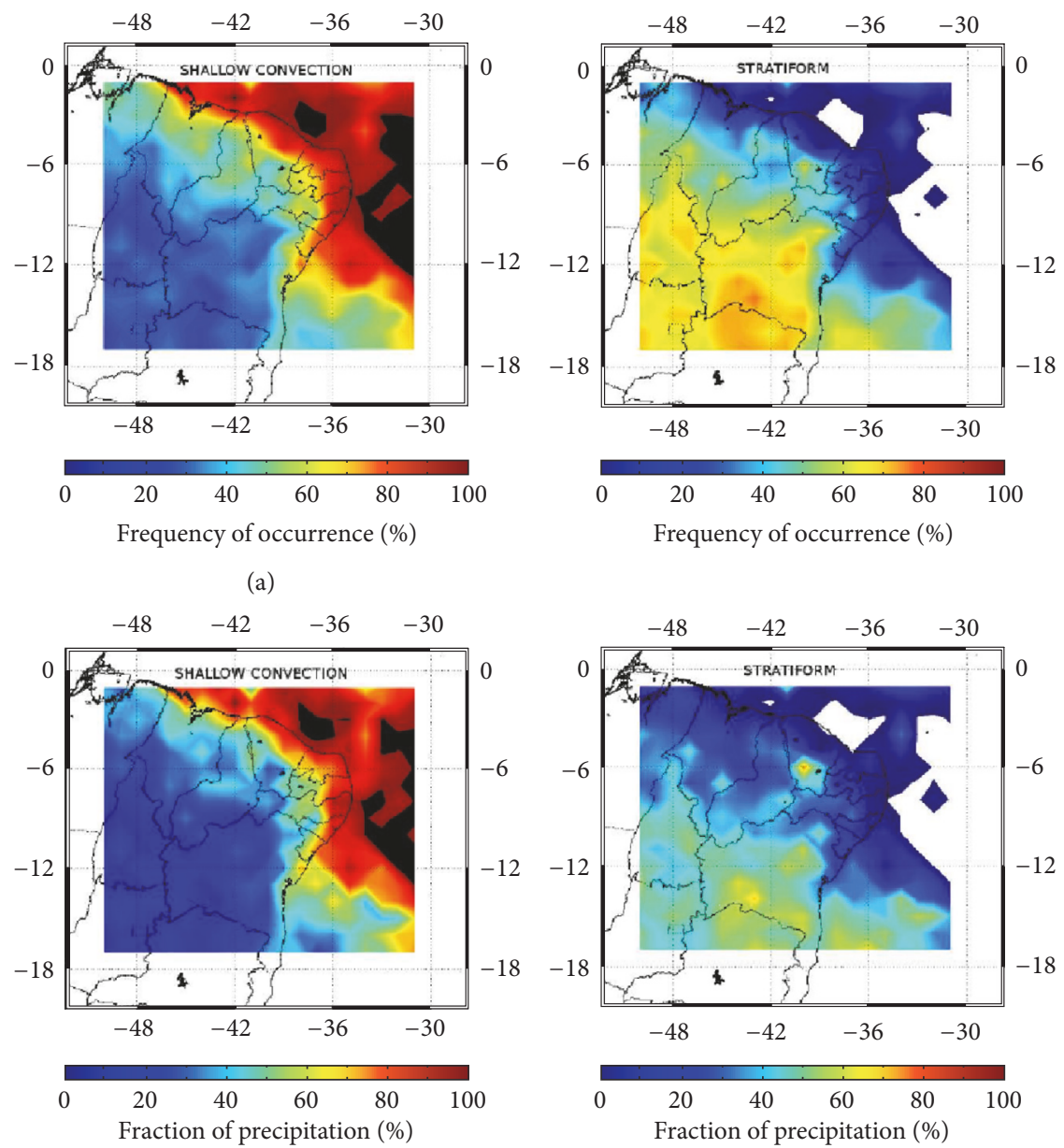

(b)

FIGURE 7: Relative frequency of events by cloud type (a) and fraction of precipitation explained by each cloud type contributing to total precipitation (b), for the month of November.

Atlantic Ocean and coastal areas of Northeast Brazil, we found that the occurrence of shallow convective clouds is higher and precipitation in the region is strongly marked by the presence of these clouds.

Another interesting result is that the stratiform and deep convective precipitating clouds are more significant to the north and west of the region, while the shallow convective clouds are important over the ocean and coastal areas.

Comparing the number of events of precipitating clouds over the continent and ocean, it was found that the amount over the continent is higher in the months of December to April for deep convective clouds and November to February for stratiform clouds, while shallow convective clouds occur more frequently over the ocean and coastal areas from March to August.

A progression of shallow convection from the ocean to the continent was observed throughout the year, which could be explained by the great influence of easterly waves associated with a northward displacement of the South Atlantic subtropical high, favoring moisture transport from the ocean to the continent. Other systems such as instability lines of moderate or weak intensity and the land/sea breeze circulation could also explain this displacement of shallow convection.

Moreover, it appears that over the 15 years studied, southern Northeast Brazil in the austral winter is strongly influenced by clouds with a vertical profile of shallow convective rain and in the austral summer by cloudiness of the stratiform type, but deep convective clouds are extremely important for the accumulated precipitation in this subregion, despite occurring at a lower frequency.

We found that eastern Northeast Brazil is basically composed of shallow convective clouds that are relatively warm and low, responsible for a significant accumulation of precipitation by the end of the rainy season. This is explained by the fact that winds are generally perpendicular to the coast and carry much moisture from the ocean to the continent, contributing to the formation of shallow clouds.

\section{Conflicts of Interest}

The authors declare that there are no conflicts of interest regarding the publication of this paper. 


\section{Acknowledgments}

The authors thank the CNPQ (National Council for Scientific and Technological Development) for the scholarship to carry out this research.

\section{References}

[1] T. D. Althoff, R. S. C. Menezes, A. L. de Carvalho et al., "Climate change impacts on the sustainability of the firewood harvest and vegetation and soil carbon stocks in a tropical dry forest in Santa Teresinha Municipality, Northeast Brazil," Forest Ecology and Management, vol. 360, pp. 367-375, 2016.

[2] J. L. Awange, F. Mpelasoka, and R. M. Goncalves, "When every drop counts: Analysis of Droughts in Brazil for the 1901-2013 period," Science of The Total Environment, vol. 566-567, pp. 1472-1488, 2016.

[3] S. Hastenrath, M. Wu, and P. Chu, "Towards the monitoring and prediction of north-east Brazil droughts," Quarterly Journal of the Royal Meteorological Society, vol. 110, no. 464, pp. 411-425, 1984.

[4] J. O. R. Aragão, "Fatos sobre o fenômeno de El Niño e sua relação com as secas no nordeste do Brasil," Boletim da Sociedade Brasileira de Meteorologia, vol. 14, pp. 2-8, 1990.

[5] A. C. Vasques, Precipitation characteristics over the South America [Master's thesis], Instituto Nacional de Pesquisas Espaciais, São José dos Campos, 2007.

[6] P. T. Oliveira, C. M. Santos E Silva, and K. C. Lima, "Climatology and trend analysis of extreme precipitation in subregions of Northeast Brazil," Theoretical and Applied Climatology, pp. 1-14, 2016.

[7] J. A. Marengo, "Mudanças climáticas e condições meteorológicas extremas," Fundação Brasileira para o Desenvolvimento Sustentável (FBDS). Mudança climática global e eventos extremos no Brasil, vol. 24, 2009.

[8] C. Uvo, A Zona de Convergência Intertropical (ZCIT) e sua relação com a precipitação da região norte e nordeste brasileiro [Master, thesis], INPE, 1989.

[9] V. E. Kousky and M. A. Gan, "Upper tropospheric cyclonic vortices in the tropical South Atlantic., Tellus, vol. 33, no. 6, pp. 538-551, 1981.

[10] H. Riehl, Waves in the easterlies and polar front in the tropics, University of Chicago Press, vol., Chicago, Chicago University, Departament of Meteorology, 1945.

[11] V. E. Kousky, "Diurnal rainfall variation in Northeast Brazil," Monthly Weather Review, vol. 108, no. 4, pp. 488-498, 1980.

[12] V. E. Kousky, "Frontal influences on northeast Brazil," Monthly Weather Review, vol. 107, no. 9, pp. 1140-1153, 1979.

[13] Y. Kodama, "Large-Scale Common Features of Subtropical Precipitation Zones (the Baiu Frontal Zone, the SPCZ, and the SACZ) Part I: Characteristics of Subtropical Frontal Zones," Journal of the Meteorological Society of Japan. Ser. II, vol. 70, no. 4, pp. 813-836, 1992.

[14] J. C. P. Cohen, M. A. SilvaDias, and C. A. Nobre, "Aspectos climatológicos das linhas de instabilidade na Amazônia," Climanálise, vol. 4, no. 11, pp. 34-40, 1989.

[15] C. R. Alcântara, M. A. Silva Dias, E. P. Souza, and J. C. Cohen, "Verification of the role of the low level jets in Amazon squall lines," Atmospheric Research, vol. 100, no. 1, pp. 36-44, 2011.

[16] M. C. Valverde Ramírez, "Padrões climáticos dos vórtices ciclônicos em altos níveis no nordeste do Brasil," Revista
Brasileira de Geofísica, vol. 17, no. 1, pp. 43-60, 1999, São José dos Campos: Oficina de textos.

[17] M. A. Gan, Um estudo observacional sobre as baixas da alta troposfera nas latitudes subtropicais do Atlântico sul e leste do Brasil [Master's thesis], Instituto Nacional de Pesquisas Espaciais- INPE, 1982.

[18] M. C. V. Ramírez, Padrões climáticos dos vórtices ciclônicos de altos nveis no nordeste do Brasil [Master's thesis], Instituto Nacional de Pesquisas Espaciais - INPE, 1996.

[19] N. O. Calbete, A. M. Gan, and I. P. Satyamurti, Vórtices ciclônicos da alta troposfera que atuam sobre a região nordeste do Brasil, Climanálise Especial - Edição comemorativa de 10 anos MCT/INPE/CPTEC, 1996.

[20] M. C. Ramirez Valverde, M. Kayano, and N. J. Ferreira, "Statistical analysis of upper tropospheric vortices in the viciviyt of northest Brazil during the 1980-1989 period," Atmosfera, vol. 12, pp. 75-88, 1999.

[21] S. K. Mishra, V. B. Rao, and M. A. Gan, "Structure and evolution of the large-scale flow and an embedded upper-tropospheric cyclonic vortex over Northeast Brazil," Monthly Weather Review, vol. 129, no. 7, pp. 1673-1688, 2001.

[22] Y. Yamazaki and V. B. Rao, "Tropical Cloudiness over the South Atlantic Ocean," Journal of the Meteorological Society of Japan. Ser. II, vol. 55, no. 2, pp. 205-207, 1977.

[23] L. A. T. Machado, M. A. F. Silva Dias, C. Morales et al., "The CHUVA project: How does convection vary across Brazil?" Bulletin of the American Meteorological Society, vol. 95, no. 9, pp. 1365-1380, 2014.

[24] G. A. Vicente, R. A. Scofield, and W. P. Menzel, "The operational GOES infrared rainfall estimation technique," Bulletin of the American Meteorological Society, vol. 79, no. 9, pp. 1883-1898, 1998.

[25] R. C. Braga, W. F. A. Lima, E. P. Vendrasco, and D. Vila, "Análise do algoritmo hidroestimador na climatologia de chuvas na região nordeste do Brasil," IV Simpósio Internacional de Climatologia: Mudanças Climáticas e Impactos em Áreas Urbanas, vol. 1, pp. 1-5, 2011.

[26] R. C. Braga, Estudo do conteúdo de gelo das nuvens em função do ciclo de vida utilizando sensores em micro-ondas passivos [Master's thesis], Instituto Nacional de Pesquisas Espaciais (INPE), São José Dos Campos, 2013.

[27] F. T. Ulaby, R. K. Moore, and A. K. Fung, "Microwave remote sensing: active and passive. Volume I: microwave remote sensing fundamentals and radiometry." Microwave remote sensing: active and passive. Volume I: microwave remote sensing fundamentals and radiometry., 1981.

[28] C. Kummerow, W. Barnes, T. Kozu, J. Shiue, and J. Simpson, "The Tropical Rainfall Measuring Mission (TRMM) sensor package," Journal of Atmospheric and Oceanic Technology, vol. 15, no. 3, pp. 809-817, 1998.

[29] T. Iguchi and R. Meneghini, "Intercomparison of single-frequency methods for retrieving a vertical rain profile from airborne or spaceborne radar data," Journal of Atmospheric \& Oceanic Technology, vol. 11, no. 6, pp. 1507-1516, 1994.

[30] C. Schumacher and R. A. Houze Jr., "The TRMM precipitation radar's view of shallow, isolated rain," Journal of Applied Meteorology, vol. 42, no. 10, pp. 1519-1524, 2003.

[31] N. J. Ferreira, C. S. Chan, and I. P. Satyamurti, "Análise dos distúrbios ondulatório de leste sobre o Oceano Atlântico equatorial sul.," in Anais do Congresso Brasileiro de Meteorologia, vol. no. 6, Salvador, Bahia, 1990. 
[32] V. B. Rao, M. C. De Lima, and S. H. Franchito, "Seasonal and interannual variations of rainfall over eastern northeast Brazil," Journal of Climate, vol. 6, no. 9, pp. 1754-1763, 1993.

[33] R. R. Torres and N. J. Ferreira, "Case studies of easterly wave disturbances over Northeast Brazil using the Eta Model," Weather and Forecasting, vol. 26, no. 2, pp. 225-235, 2011.

[34] Y. Kodama, "Large-scale common features of subtropical precipitation zones (the Baiu Frontal Zone, the SPCZ, and the SACZ).Part II: Conditions for gerenating the STCZ s," Journal of Meteorological of Society of Japan, vol. 71, pp. 581-610, 1992.

[35] P. Satyamurti, C. Nobre, and P. L. SilvaDias, South America: Meteorology of the southern hemisphere, American Meteorological Society, Boston, MA, 1998.

[36] L. M. V. Carvalho, C. Jones, and B. Liebmann, "Extreme precipitation events in southeastern South America and large-scale convective patterns in the South Atlantic covergence zone," Journal of Climate, vol. 15, no. 17, pp. 2377-2394, 2002.

[37] D. Waliser and X. Jian, "Tropical meteorology and climate Intertropical Convergence Zone," in Reference Module in Earth Systems and Environmental Sciences Encyclopedia of Atmospheric Sciences, 2015.

[38] L. M. V. Carvalho and C. Jones, "Zona de Convergência do Atlântico Sul," Tempo e Clima no Brasil.

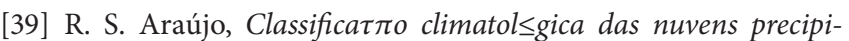
tantes no nordeste brasileiro utilizando dados do Classificação climatológica das nuvens precipitantes no nordeste brasileiro utilizando dados do radar a bordo do satélite TRMM [Master, thesis], Instituto Nacional de Pesquisas Espaciais (INPE), São José Dos Campos, 2015.

[40] A. B. C. D. Melo, Previsibilidade da precipitação na região semiárida do nordeste do Brasil, durante a estação chuvosa, em função do comportamento diário das chuvas na pré-estação [Master's thesis], Departamento de Ciências Atmosféricas (DCA), Federal University of Paraíba, 1997.

[41] V. Kousky and P. S. Chu, "Fluctuations in annual rainfall for northeast Brazil," Journal of the Meteorological Society of Japan, vol. 56, pp. 457-465, 1978. 

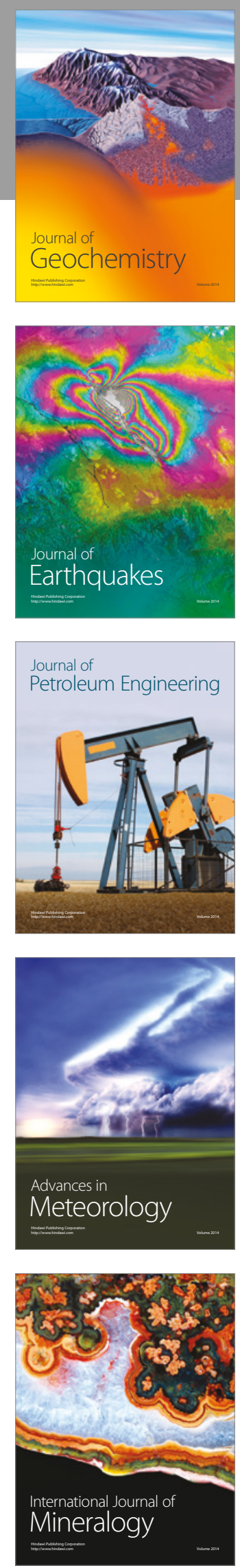
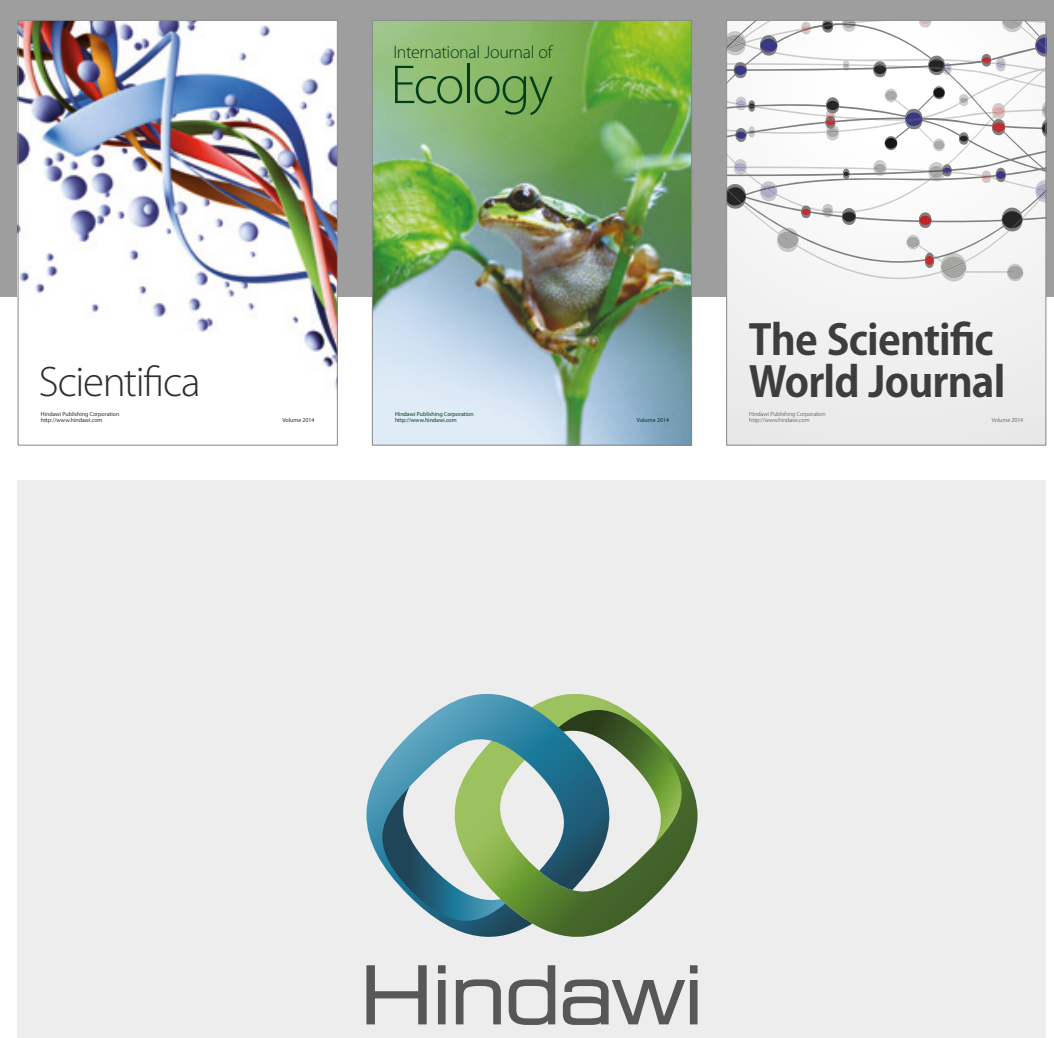

Submit your manuscripts at

https://www.hindawi.com
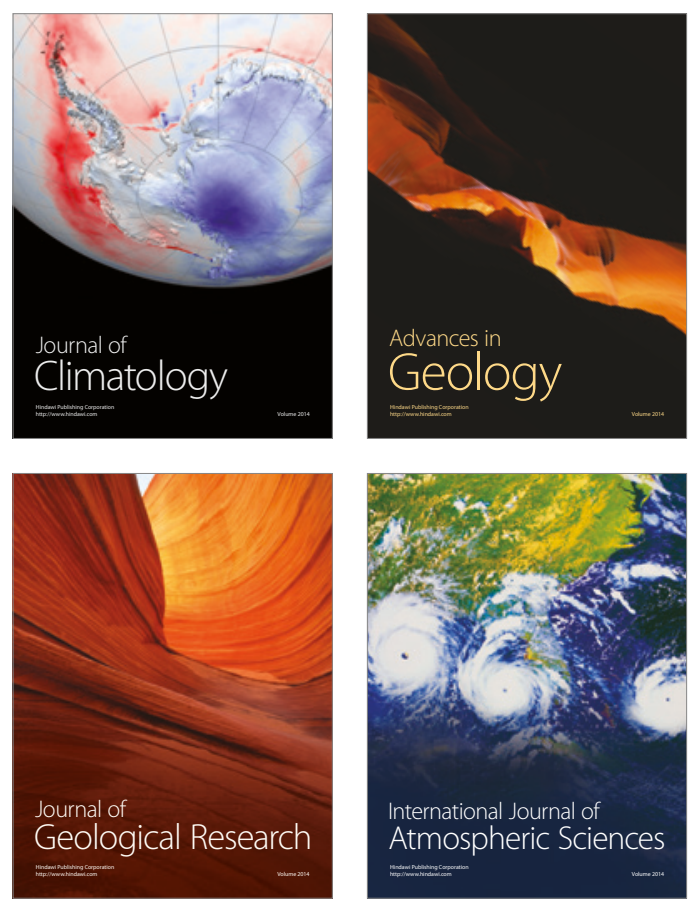

The Scientific

World Journal
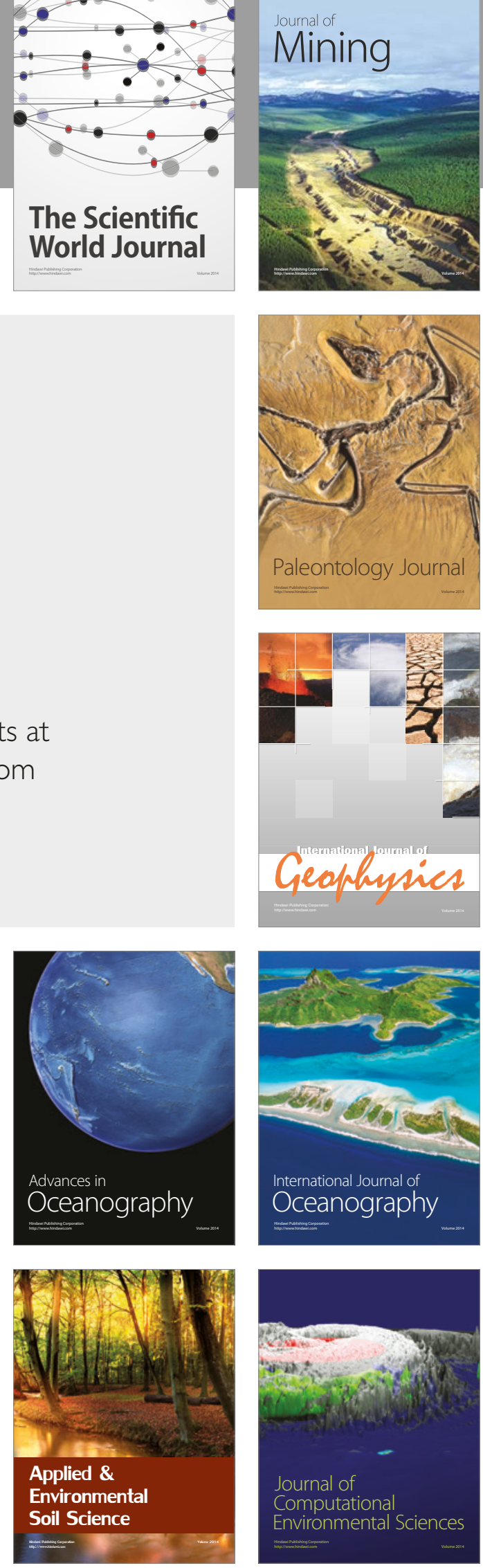